\title{
Quantitative Analyses of Soil Algae in the Balaton Upland National Park (Hungary)
}

\author{
${ }^{1}$ A. LEPOSSA and ${ }^{2}$ V. ÖRDÖG \\ ${ }^{1}$ Károly Róbert College, Faculty of Agriculture, Gyöngyös and ${ }^{2}$ University of West \\ Hungary, Faculty of Agricultural and Food Sciences, Mosonmagyaróvár (Hungary)
}

Detailed investigations on algae living in soils started at the beginning of the last century. These studies lead to a great number of scientific publications about the biology, ecology and taxonomy of soil algae, from case studies to general reviews.

In Hungary, research on soil algae started in the 1930's, when FEHÉR (1936) wrote the first and so far only report on the quantity of algae in Hungarian soils. He observed that the richest algal flora appeared in rainy months in autumn (FEHÉR, 1954). The effects of meteorological factors on soil algae were investigated by KISS $(1955,1959)$. He presumed that the so-called water-blooming and soil-blooming are analogous phenomena. He noticed that diverse algal flora appeared on the soil surface depending on the variation of light. The results of the floristic studies on several Hungarian soils by KOMÁROMY $(1975,1976,1979,1983,1985)$ were valuable contributions to soil algology.

The knowledge revealed so far indicates that algal communities in soils are affected by several abiotic and biotic environmental factors, and the rules of their interactions have not been fully clarified as yet. Further laboratory experiments as well as field studies are required for this purpose.

The aims of the present study were to investigate the monthly variations of algal abundance in soils of the Balaton Upland National Park (Hungary), to estimate the active algal biomass by a direct cell counting method, as well as to determine the factors that influence the changes in algal cell numbers, and the rate of these influences by statistical approach.

\section{Materials and Methods}

Sampling areas. - Six areas on three different soil types were chosen in the Tapolcai and Káli Basins, and in the Tihany Peninsula. At the sampling sites cultivated and uncultivated areas of 0.5 hectare size were chosen (Table 1). Before sampling the soil surface was cleared from vegetation.

Correspondence to: ANITA LEPOSSA, Károly Róbert College, Department of Environmental Management and Agronomy, H-3200 Gyöngyös, Mátrai út 36. E-mail: lepossaa@karolyrobert.hu 
Table 1

The location of the sampling areas, soil types and type of cultivation

\begin{tabular}{|c|c|c|c|}
\hline Code & $\begin{array}{l}\text { Location of sam- } \\
\text { pling area }\end{array}$ & Soil type & Type of cultivation \\
\hline $\begin{array}{l}\text { I.a } \\
\text { I.b }\end{array}$ & $\begin{array}{l}\text { Szigliget } \\
\text { Balatonederics }\end{array}$ & fen soil & $\begin{array}{l}\text { corn field } \\
\text { meadow }\end{array}$ \\
\hline $\begin{array}{l}\text { II.a } \\
\text { II.b }\end{array}$ & $\begin{array}{l}\text { Tihany } \\
\text { Tihany }\end{array}$ & rendzina & $\begin{array}{c}\text { lavender field } \\
\text { meadow }\end{array}$ \\
\hline $\begin{array}{l}\text { III.a } \\
\text { III.b }\end{array}$ & $\begin{array}{l}\text { Mindszentkálla } \\
\text { Mindszentkálla }\end{array}$ & $\begin{array}{l}\text { Ramann-type brown } \\
\text { forest soil }\end{array}$ & $\begin{array}{l}\text { sunflower-winter wheat culture } \\
\text { meadow }\end{array}$ \\
\hline
\end{tabular}

Soil sampling for algal quantitative analyses. - Soil samples were collected in duplicates at five-five randomly chosen sampling sites in every sampling area at monthly intervals between April 1999 and March 2000. Sample collection from the upper $(0-1 \mathrm{~cm})$ soil layer was done with a spatula (sterilized with alcohol and heat), from the $1-10 \mathrm{~cm}$ layer undisturbed soil samples were collected with aluminum cylinder $(3.6 \times 10 \mathrm{~cm})$ closed at both ends with aluminum foils. Five subsamples were taken in a plastic bag and closed leaving enough air inside. Samples were kept in a cool, dark place for up to three days. Subsamples were homogenized before the algal cell counting.

Cell counting, biomass estimation. - A direct cell counting method based on chlorophyll autofluorescence was used for measuring active algal cells in the soils. Soil preparation and microscopic cell counting were done according to LUKEŠOVÁ (1994). $10 \mathrm{~g}$ of fresh soil was diluted up to $100 \mathrm{ml}$ in sterile distilled water in 250 $\mathrm{ml}$ flasks. Soil suspensions were shaken in an ultrasound bath (Tesla UC 002 BM1, $50 \mathrm{~Hz}$ ) for $4 \mathrm{~min}$. Algal cells were counted under an Olympus BX60 epifluorescent microscope. To identify cyanobacteria a green filter (WG, ex. 510-550 nm, em. $610+$ ), and for identifying green algae a blue filter (NBV, ex. 420-440 nm, em. $455+$ ) was applied. After shaking, soil suspensions were left to sedimentate for 30 seconds, then $20 \mu \mathrm{L}$ supernatant was placed on a microscopic slide by a micropipette and covered with a $22 \times 22 \mathrm{~mm}$ sized cover slip. The total area under the cover slip was scanned by microscope. Three different algal groups were studied: $\mathrm{Cb}$ (cyanobacteria), D (diatoms), Eu-D (other eukaryotic algae). Cell counting was carried out in triplicates. Parameters of the most frequent species in different algal groups and the geometric means of monthly cell numbers were taken into consideration to estimate active algal biomass. Cellular mass was determined according to NÉMETH (1998).

Measurement of environmental parameters. - Data of some meteorological factors (sum of rainfall, average temperature, average minimum radiation, average hours of sunlight) were collected from daily reports of the Meteorological Station, Keszthely, while soil and air temperature were measured at sample collection. The following soil analyses were done in the laboratory: determination of actual water content (20 g fresh soil, $105^{\circ} \mathrm{C}, 24 \mathrm{~h}$ ) according to GYÖRI et al. (1990); pH meas- 
urement of fresh soils $(5 \mathrm{~g}$ fresh soil $+12.5 \mathrm{ml}$ distilled water, RADELKIS OP264/1 ammonium- and pH-measuring instrument) according to HORVÁTH (1980); soil volume weight according to GYÖRI et al. (1990); mechanical analysis by the Atterberg-method (Dept. Soil Sci. and Water Management, West Hung. Univ., Fac. Agr. Sci.); and nutrient content determination according to the MSZ 20135/1999 Hungarian standard (Station of Plant Health and Soil Protection, Fejér County).

Statistical analysis. - In order to compare the different soil types cell numbers were calculated to unit soil volume $\left(1 \mathrm{~cm}^{3}\right)$, as recommended by OESTERREICHER (1988). For this purpose the cell numbers in $1 \mathrm{~g}$ air-dry soil were modified by the volume weight of different soils. Log-transformation was applied on data according to HUNT et al. (1979). A t-test ( $\mathrm{P}=5 \%$ ) was applied to test the differences between algal cell numbers in the two repetitions of the same sampling site. For further statistical analyses average cell numbers composed from two repetitions of each sampling site were used. The effects of soil type, season, cultivation and soil depth on algal abundance were evaluated by Analysis of Variance (ANOVA) according to KEMÉNY and DEÁK (2000). Forward Regression Analysis was applied to determine the effect of observation variables on the cell numbers (STATISTICA software 1984-2000).

\section{Results and Discussion}

\section{Environmental factors}

The highest values for both temperature and sunlight hours during the whole investigated period were detectable in July. Minimum values for temperature and sunlight hours were in January and in December, respectively. The sum of rainfall showed its maximum in June, but smaller peaks were recorded in April and November. Rainfall minimum was in autumn (Sept-Oct) and in December.

Soils I.a and II.a had a loamy, I.b and II.b a sandy loam, while III.a and III.b a clay loam texture. The plasticity values for cultivated soils were higher than those for meadows in case of each soil type. Similar relationships were established for the humus and sulphate content of soils. The content of inorganic nitrogen forms $\left(\mathrm{NH}_{4^{-}}, \mathrm{NO}_{2^{-}}, \mathrm{NO}_{3}-\mathrm{N}\right)$ and the total nitrogen content were the lowest in the lavender field (II.a). The highest soluble sulphate content was measured in the Ramann-type brown forest soil (III.a, III.b), while fen soils (I.a and I.b) were the poorest in potassium. Soil III.a had relatively high concentrations of iron and some microelements ( $\mathrm{Mn}, \mathrm{Cu}, \mathrm{B}, \mathrm{Al}, \mathrm{Co}, \mathrm{Ni}, \mathrm{Pb}$ ). Their better solubility can be explained by the slightly acidic $\mathrm{pH}$ of the soil. Soil I.a was slightly alkaline, while the $\mathrm{pH}_{(\mathrm{KCl})}$ of others was neutral.

\section{Characterization of the algal flora and calculated biomass}

Based on the cell numbers obtained during the whole investigation period, it was found that cyanobacteria reached at least $30 \%$ of the total algal content in each soil type. Their rate was extremely high in the lavender field (76\%), however, this phe- 
nomenon cannot be explained entirely with the environmental factors investigated in this study. Diatoms showed their highest rate in the fen soil (13\%), but their average rate was $4 \%$ in cultivated soils and $8-9 \%$ in meadows. Out of all of the investigated soils the cultivated fen soil was the richest in diatoms, while the meadow on Ramann-type brown forest soil was the poorest. The average abundance of other eukaryotic algae (Eu-D group) was $40-50 \%$ in the investigated soils (Fig. 1).

The filamentous Nostoc and Cylindrospermum species dominated in the cyanobacterial flora of each soil, while Navicula spp. belonging to the diatoms were observed most often. Genuses belonging to Chlorophyceae, like Chlorella, Chlorococcum, Tetracystis and Chlamydomonas, represented the other eukaryotic algal group.

Calculating algal biomass with the cell parameters of the most frequent genuses, the estimated mass of a cyanobacterial cell was $0.458 \cdot 10^{-10} \mathrm{~g}$, while this value of a
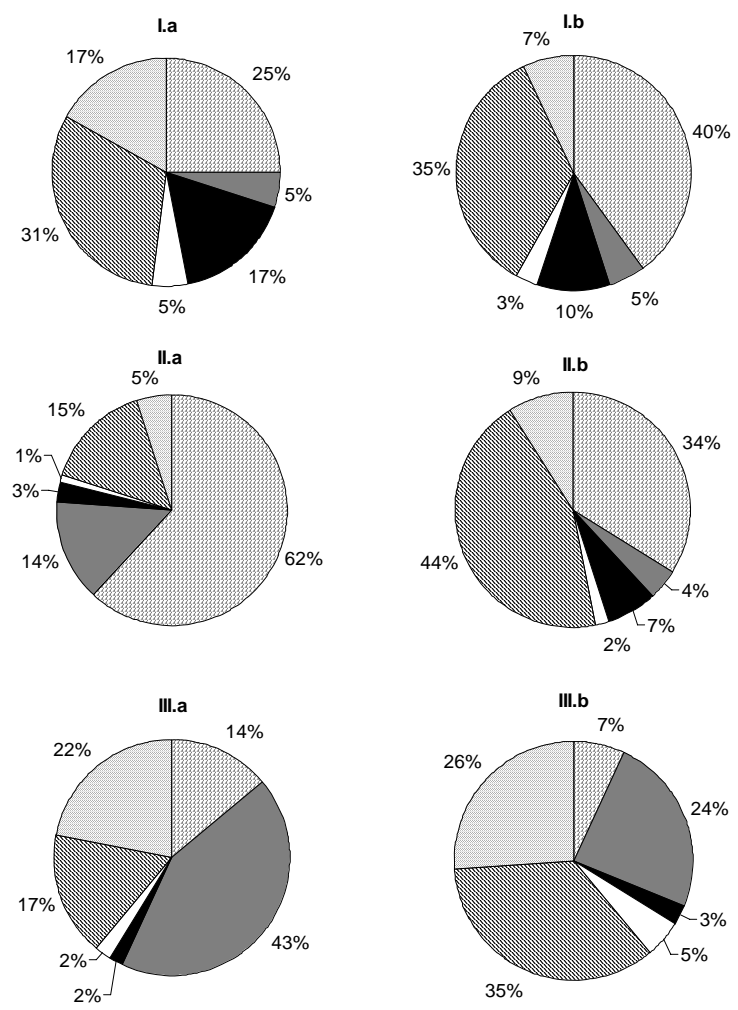

$\square \mathrm{Cb}(0-1) \quad \square \mathrm{Cb}(1-10) \quad \square \mathrm{D}(0-1) \quad \square \mathrm{D}(1-10) \quad \mathrm{Eu}-\mathrm{D}(0-1) \quad \square \mathrm{Eu}-\mathrm{D}(1-10)$

Fig. 1

Percentage distribution of investigated algal groups [cyanobacteria $(\mathrm{Cb})$, diatoms (D) and other eukaryotic algae (Eu-D group)] in the cultivated (a) and uncultivated (b) fen soil (I), rendzina (II) and Ramann-type brown forest soil (III) 
diatomal cell was $4.712 \cdot 10^{-10} \mathrm{~g}$, and $9.048 \cdot 10^{-10} \mathrm{~g}$ for a cell in the Eu-D group. Table 2 shows the average cell numbers and calculated algal biomass in the $0-10$ $\mathrm{cm}$ soil layer during the investigated period. The average viable algal cell numbers in the whole investigated soil layer were between $46 \cdot 10^{3}$ and $432 \cdot 10^{3}$ cells $\cdot \mathrm{cm}^{-2}$. It can be concluded from the biomass results that at least $1 \mathrm{~kg}$ viable algal mass per

Table 2

Average cell numbers of the studied algal groups and calculated active biomass in the whole investigated soil layer $(0-10 \mathrm{~cm})$

\begin{tabular}{|l|r|r|r|r|r|r|}
\hline \multirow{2}{*}{ Algal group } & \multicolumn{7}{|c|}{ Investigated soil* } \\
\cline { 2 - 7 } & I.a & I.b & II.a & II.b & IIIa. & III.b \\
\hline \multicolumn{7}{|c|}{ Average algal cell number $\left(10^{3}\right.$ cells $\mathrm{cm}^{-2}$ soil $)$} \\
Cyanobacteria & 102 & 82 & 332 & 62 & 213 & 13 \\
Diatoms & 83 & 11 & 16 & 12 & 15 & 4 \\
Other eukaryotic algae & 184 & 48 & 84 & 78 & 142 & 29 \\
Total & 369 & 141 & 432 & 152 & 370 & 46 \\
\multicolumn{7}{|c|}{ Calculated average algal biomass } \\
Cyanobacteria & 0.47 & 0.38 & 1.52 & 0.28 & 0.98 & 0.06 \\
Diatoms & 3.93 & 0.53 & 0.75 & 0.57 & 0.72 & 0.18 \\
Other eukaryotic algae & 16.66 & 4.33 & 7.56 & 7.09 & 12.88 & 2.63 \\
Total & 21.06 & 5.23 & 9.83 & 7.94 & 14.58 & 2.87 \\
Minimum & 1.05 & 1.35 & 1.50 & 1.74 & 2.44 & 1.10 \\
Maximum & 79.95 & 13.30 & 23.10 & 13.89 & 35.63 & 6.04 \\
Geometric mean & 11.18 & 4.30 & 7.12 & 6.94 & 10.69 & 2.47 \\
\hline
\end{tabular}

* See Table 1

hectare is always present in the upper $10 \mathrm{~cm}$ soil layer. The highest biomass value $\left(80 \mathrm{~kg} \cdot \mathrm{ha}^{-1}\right)$ measured during the investigation period was detected in the fen soil, on the cornfield, due to the high rate and cell volume weight of diatoms. High abundance values do not necessarily indicate high biomass, as it can be seen in Table 2, where soil II.a was extremely rich in cyanobacteria and showed the highest average cell number, but it was only third from the point of view of biomass.

The average algal cell numbers converted to $1 \mathrm{~g}$ dry soil in the present study are lower (below 1 million cells in $1 \mathrm{~g}$ soil) than some results found in literature (SHTINA, 1959; HUNT et al., 1979; LUKEŠOVÁ, 1993), where 5-6 or even 27 million cells per $\mathrm{g}$ dry soil were counted. The calculated algal biomass values from our studies are also smaller. The difference can be explained by the fact that the applied cell counting method differed (usually indirect cell counting methods, which measure the viable and not only the active algal cells).

\section{Statistical analyses}

ANOVA of environmental factors showed that soil type had a significant effect $(\mathrm{P}<1 \%)$ on cyanobacterial and diatomal abundance. From all investigated areas, 
the highest cyanobacterial abundance was observed in the upper layer of rendzina soils. The Ramann-type brown forest soil differed from the others, as the upper layer was the poorest, while the deeper soil layer was the richest as regards average cyanobacterial cell numbers. The prolification of cyanobacteria was the best in rendzina soils, and the worst in fen soils. A significant difference $(\mathrm{P}=1 \%)$ was measured between the cyanobacterial abundance of these two soils. The highest average diatomal cell number was observed in the fen soil, significantly differing (P $<1 \%)$ from the brown forest soil.

The seasonal effect on the total algal cell numbers in soils appeared with minimum values in spring and maximum values in summer. Some insignificant peaks also occurred in winter (Nov-Dec-Jan). This seasonal factor had a greater effect on the other eukaryotic algal group (Eu-D) than on cyanobacteria or diatoms. Significant differences were recorded in the monthly abundance values of eukaryotic algae. Cell numbers showed a peak in summer. The algal abundance was significantly $(\mathrm{P}<5 \%)$ higher in the winter season as compared to the minimum values registered in spring. In the case of cell numbers of cyanobacteria and diatoms, the annual dynamics were more intensive in cultivated soils. No significant changes in algal abundance were measured in the deeper soil layers during the whole investigated period.

It can be stated that cultivation has a positive effect on algal abundance. The average total algal cell numbers in the upper $10 \mathrm{~cm}$ layer of cultivated soils $\left(2.7 \cdot 10^{5}\right.$ cells $\left.\mathrm{cm}^{-3}\right)$ were significantly $(\mathrm{P}=0.1 \%$ ) higher than in uncultivated meadows $\left(8.5 \cdot 10^{4}\right.$ cells $\left.\mathrm{cm}^{-3}\right)$. The differences were $2.6-2.8$-fold in fen and rendzina soils, while more than 8 -fold in the Ramann-type brown forest soil.

Soil depth also greatly affected algal abundance. $1 \mathrm{~cm}^{3}$ soil from the upper $1 \mathrm{~cm}$ layer contains significantly $(\mathrm{P}<0.1 \%)$ more algal cells than the deeper soil layer. On the average of investigated areas, approximately $70 \%$ of the algal cells in the whole studied soil depth $(0-10 \mathrm{~cm})$ were found in the upper $1 \mathrm{~cm}$ layer. The Ramann-type brown forest soil differs from the other soil types, as the ratio of algal cells was $33: 67 \%$ in the cultivated area, and $45: 55 \%$ in meadow in the $0-1 \mathrm{~cm}$ and $1-10 \mathrm{~cm}$ soil layers, respectively.

Forward regression analyses showed that the humus content of soils was the most important factor from the viewpoint of decreasing cyanobacterial cell numbers, which explains the lower cyanobacterium abundance in meadows. The nitrogen content of soils - total and available nitrogen forms as well - also seemed to be an important factor in negative connection with cyanobacterial abundance. Their frequent occurrence in rendzina soils is probably a result of the low available nitrogen and higher potassium content of these soils. The actual water content of soils was in positive correlation with cyanobacterial cell numbers.

A high positive correlation was established between the $\mathrm{CaCO}_{3}$ content of soils and diatomal cell numbers. This is the probable cause of their greater abundance in fen soils. Maximum diatomal cell number values during summer can be explained by high air temperature measured at sampling on the basis of regression analysis. Humus content, plasticity, zinc concentration and actual $\mathrm{pH}$ of soil had negative 
effects, while the actual water content of soils was in positive correlation with diatomal abundance.

In the case of the abundance of other eukaryotic algae (Eu-D), the actual $\mathrm{pH}$ of soils was the most important factor. A negative correlation was established between the actual $\mathrm{pH}$ of soil and abundance of Eu-D. The appearance of this algal group was affected negatively by the humus content, and positively by the actual water content of soils.

Taking all measured factors (soil and meteorological parameters) into consideration, regression analyses showed that only $16.1 \%, 14.6 \%$ and $8 \%$ from the total variance in the abundance of cyanobacteria, diatoms and other eukaryotic algae, respectively, are explainable by these factors.

\section{Conclusions}

The direct cell counting method based on chlorophyll autofluorescence applied in this study was correct for investigating the responses of soil algae to changes in environmental factors. For following cell counting experiments the use of at least two categories - cyanobacteria and eukaryotic algae - is suggested due to the differences in their average cell mass, and in the ecological demands of these algal groups.

The results of the present regression analyses indicate that the seasonal variation in algal cell numbers depending on environmental factors could be better explained by more frequent cell counting.

\section{Summary}

Monthly variations of the algal abundance in different soils of the Balaton Upland National Park were measured by a direct cell counting method in a one year long investigation. Variance and regression analyses were used to evaluate the effects of environmental factors on the quantitative changes in algae. Results underlined the basic role of soil depth and cultivation, while soil type had a significant effect on cyanobacteria and diatoms. The seasonal effect in the abundance of eukaryotic algae was registered by summer maximum cell numbers.

Taking all three investigated algal groups into consideration, the humus content of soil seemed to be the most important factor, being in negative correlation with their abundance, while the actual water content of soil had a slight positive effect on cell numbers. A negative correlation was found between the nitrogen content of soil and cyanobacterial abundance. The carbonate content of soils had a positive effect, while plasticity, zinc concentration and the actual $\mathrm{pH}$ of soil were in negative correlation with diatomal abundance. The actual $\mathrm{pH}$ of soils was the most important factor in the negative correlation with other eukaryotic algal abundance.

Coefficients of determination showed that only $16.1 \%, 14.6 \%$ and $8 \%$ of the total variance in the abundance of cyanobacteria, diatoms and other eukaryotic algae, respectively, can be explained by measured soil and meteorological parameters. 
Key words: soil algae, direct cell count, biomass, Balaton Upland National Park

\section{References}

FEHÉR, D., 1936. Über die Algenflora des Waldbodens. Silva. 24. (13) 101-108.

FeHÉR, D., 1954. Soil Biology. (In Hungarian) Akadémiai Kiadó. Budapest.

GYöRI, D., PALKOVICS, M.-NÉ \& M. SÉNYI, K., 1990. In situ and Laboratory Soil Analyses. (In Hungarian) Pannon Agricultural University of Sciences. Keszthely.

HoRvÁth, S., 1980. Practical Guidebook on Microbiology. (In Hungarian) Tankönyvkiadó. Budapest.

Hunt, M. E., Floyd, G. L. \& Stout, B. B., 1979. Soil algae in field and forest environments. Ecology. 60. (2) 362-375.

KeMÉNY, S. \& DEÁK, A., 2000. Design and Analysis of Experiments. (In Hungarian) Müszaki Könyvkiadó. Budapest.

KISS, I., 1955. Life of vegetative microorganisms in soils and the weather. (In Hungarian) Időjárás. 59. 339-343.

KISS, I., 1959. A synoptic-meteorobiological analysis of "soil-bloom". (In Hungarian) Agrokémia és Talajtan. 8. 49-58.

KoMÁROMY, Zs. P., 1975. Comparative algological studies in some soil types of the Mátra Mts. Acta Bot. Acad. Sci. Hung. 21. 289-304.

KOMÁROMY, Zs. P., 1976. Soil algal growth types as edaphic adaptation in Hungarian forest and grass steppe ecosystems. Acta Bot. Acad. Sci. Hung. 22. 373-379.

KoMÁROMY, Zs. P., 1979. Algal flora of Hungarian sandy soils. I. Some algological investigations in Kiskunság National Park, Hungary. Ann. Hist.-nat. Mus. Nat. Hung. 71. 58-63.

KOMÁROMY, Zs. P., 1983. A comparative study on the algal synusia of Hungarian grasslands and deciduous forests. Ann. Hist.-nat. Mus. Nat. Hung. 75. 47-53.

KoMÁROMY, Zs. P., 1985. The role of algal synusia of grasslands in successional processes in Hungary. Ann. Hist.-nat. Mus. Nat. Hung. 77. 97-102.

LUKEŠOVÁ, A., 1993. Soil algae in four secondary successional stages on abandoned fields. Algol. Stud. 71. 81-102.

LUKEŠOVÁ, A., 1994. Enumeration of soil algae using epifluorescency. (In Czech) In: Kultivační a mikroskopické metody studia počtu mikroorganismů v půdě. Sborník př́spěvků ze semináře. (Eds: KRIŠTƯFEK, V. \& LUKEŠOVÁ, A.) 53-56. ÚPB AVČR. České Budějovice.

NÉMETH, J., 1998. Estimation of the biomass of phytoplankton. In: Methods of Biological Qualification of Water. (In Hungarian) VTKV-7. 132-139.

OesterREICHER, W., 1988. Quantitative Erfassung der Bodenalgenflora mit dem Fluorezenzmikroskop. Leitz Mitt. u. Techn. 9. (3) 112-116.

SHTINA, E. A., 1959. The algal communities of the main soil types of the USSR and their diagnostic significance. Bot. Zhurn. 44. 1062-1074. 